\title{
Applicability of cryoconite consortia of microorganisms and glacier-dwelling animals in astrobiological studies
}

\author{
Krzysztof Zawierucha $^{1 *}$, Marta Ostrowska², Małgorzata Kolicka ${ }^{1}$ \\ ${ }^{1}$ Department of Animal Taxonomy and Ecology, Faculty of Biology, Adam Mickiewicz University in Poznań, \\ Umultowska 89, 61-614 Poznań, Poland, \\ ${ }^{2}$ Department of Avian Biology and Ecology, Faculty of Biology, Adam Mickiewicz University in Poznan, \\ Umultowska 89, 61-614 Poznań, Poland, \\ *corresponding author: k.p.zawierucha@gmail.com
}

Received: $20^{\text {th }}$ February, 2016

Accepted: $15^{\text {th }}$ February, 2017

\begin{abstract}
For several years it has been of interest to astrobiologists to focus on Earth's glaciers as a habitat that can be similar to glaciers on other moons and planets. Microorganisms on glaciers form consortia - cryoconite granules (cryoconites). They are granular/spherical mineral particles connected with archaea, cyanobacteria, heterotrophic bacteria, algae, fungi, and micro animals (mainly Tardigrada and Rotifera). Cryophilic organisms inhabiting glaciers have been studied in different aspects: from taxonomy, ecology and biogeography, to searching of biotechnological potentials and physiological strategies to survive in extreme glacial habitats. However, they have never been used in astrobiological experiments. The main aim of this paper is brief review of literature and supporting assumptions that cryoconite granules and microinvertebrates on glaciers, are promising models in astrobiology for looking for analogies and survival strategies in terms of icy planets and moons. So far, astrobiological research have been conducted on single strains of prokaryotes or microinvertebrates but never on a consortium of them. Due to the hypothetical similarity of glaciers on the Earth to those on other planets these cryoconites consortia of microorganisms and glacier microinvertebrates may be applied in astrobiological experiments instead of the limno-terrestrial ones used currently. Those consortia and animals have qualities to use them in such studies and they may be the key to understanding how organisms are able to survive, reproduce and remain active at low temperatures.
\end{abstract}

Key words: astrobiology, extremophiles, icy planets, icy moons, invertebrates

\section{Introduction}

The Earth is not the only celestial body partially covered with ice in the Universe. Other planets and moons in our Solar System are also covered with ice caps as well as glaciers (see e.g., Fishbaugh and Head 2000; Sotin and Tobie 2004; Greenberg 2005). Because of some similarities (e.g., low temperatures, strong seasonality, frigid surface, dust transportation by wind), the biological processes of glaciers on Earth can hypothetically be analogous to those on other moons and planets in the Solar System (e.g.,
Tranter et al. 2004; Doran et al. 2010). Only limited data exist on the biochemical processes on glaciers as analogues to similar habitats beyond Earth (e.g., Tranter et al. 2004). So far, more data were published on geological events and landscape analogues of Earth to other planets (e.g., Wilson and Head 1981; Doran et al. 2010; Head and Marchant 2014). Principal examples are icy moons or planets with ice caps, and findings of landscape and climate analogues in McMurdo Dry Valley in Antarctica (e.g., Doran et al. 2010; Marchant and Head 2014). 
Glaciers and ice sheets (Fig.1A) constitute ca. $10 \%$ of Earth's surface and form a viable extreme biome (Anesio and Laybourn-Parry 2012). Despite the fact that the surface of glaciers is frozen for most of the year, and these places are mainly located in areas with high doses of UV radiation, they are a habitat for numerous microorganisms living in cryoconites aggregations (Fig.1C) and cryoconite holes (Fig.1B) and lakes (e.g., Wharton et al. 1985; Takeuchi et al. 2001; Hodson et al. 2008; Zawierucha et al. 2015).

Cryoconite granules (cryoconites) are consortia formed by microorganisms (Figs 1C and 1D). They are granular/spherical mineral particles connected with archaea, algae, cyanobacteria, fungi, heterotrophic bacteria and micro animals (mainly Tardigrada and Rotifera), the latter feed on these consortia (Figs 1C and 1D, Figs 2A and 2B). Forming of cryoconite granules is possible because of extra polymeric substances produced by cyanobacteria which cause the aggregation of mineral dust and other organisms (Figs $1 \mathrm{C}$ and 1D) (Takeuchi et al. 2001; Hodson et al. 2008, 2010; Langford et al. 2014; Cook et al. 2015; Uetake et al. 2016). The decreasing of albedo induced by cryconites influences the formation of cryoconite holes. Those holes are waterfilled reservoirs with cryoconite sediment on the floor, that occurs on glacier surfaces throughout the world (Fig.1B). The development and functioning of these ecosystems is possible due to decrease in albedo on the surfaces of mineral and organic dust-covered glaciers, the presence of cryophilic microorganisms and the existence of truncated trophic webs (e.g., Takeuchi et al. 2001; Hodson et al. 2008; Cook et al. 2015; Zawierucha et al. 2015, 2016a). Cryoconite sediments on glaciers and in cryoconite holes are one of the most extremophile organisms consortia which appear on all investigated glaciers from polar to high alpine regions (e.g., Porazińska et al. 2004; Hodson et al. 2008; Cook et al. 2015; Zawierucha et al. 2016b). To date, cryophilic organisms inhabiting glaciers (cryoconites and cryoconite holes) have been studied in different aspects: from taxonomy, ecology and biogeography, to searching of biotechnological potentials and physiological strategies to survive in cryoconite holes (e.g., Hodson et al. 2008; Singh et al. 2014a,b; Grzesiak et al. 2015; Lutz et al. 2016; Uetake et al. 2016; Zawierucha et al. 2016a). However, they have never been used in astrobiological experiments. The main aim of this paper is brief review of literature and supporting assumptions that cryoconite granules and microinvertebrates on glaciers are proper models in astrobiology.

Environmental conditions in polar deserts, ice caps and glaciers may constitute a climatic analogy to icy planets or moons (Doran et al. 2010). One of the best examples is McMurdo Dry Valley, with one of the coldest and driest climate on Earth (Doran et al. 2010). Numerous publications on terrestrial glaciers and their analogous in space have been published in the last few years (e.g., Hoover and Gilichinsky 2001; Doran et al. 2010; Chela-Flores and Seckbach 2011; Dudeja et al. 2012; Marchant and Head 2014). However, scientific browsers such as Web of Knowledge and SCOPUS list few publications with keywords such as "glaciers" and "astrobiology" i.a. only twenty two and twenty five papers respectively (http://apps. webof knowledge.com/ accessed 25.10.2016, https:// www.scopus.com/ 25.10.2016).

\section{Cryoconite consortia}

Microbes which inhabit glaciers and polar regions are adapted to the most extreme cold conditions and can be found e.g., in areas of blue ice, in accreted ice of Lake Vostok, in soil from McMurdo Dry Valley or under Greenland's ice cap (e.g. Karl et al. 1999; Priscu et al. 1999; Christner et al. 2001; Sheridan et al. 2003; Doran et al. 2010; Hodson et al. 2013). Single-cell organisms are 

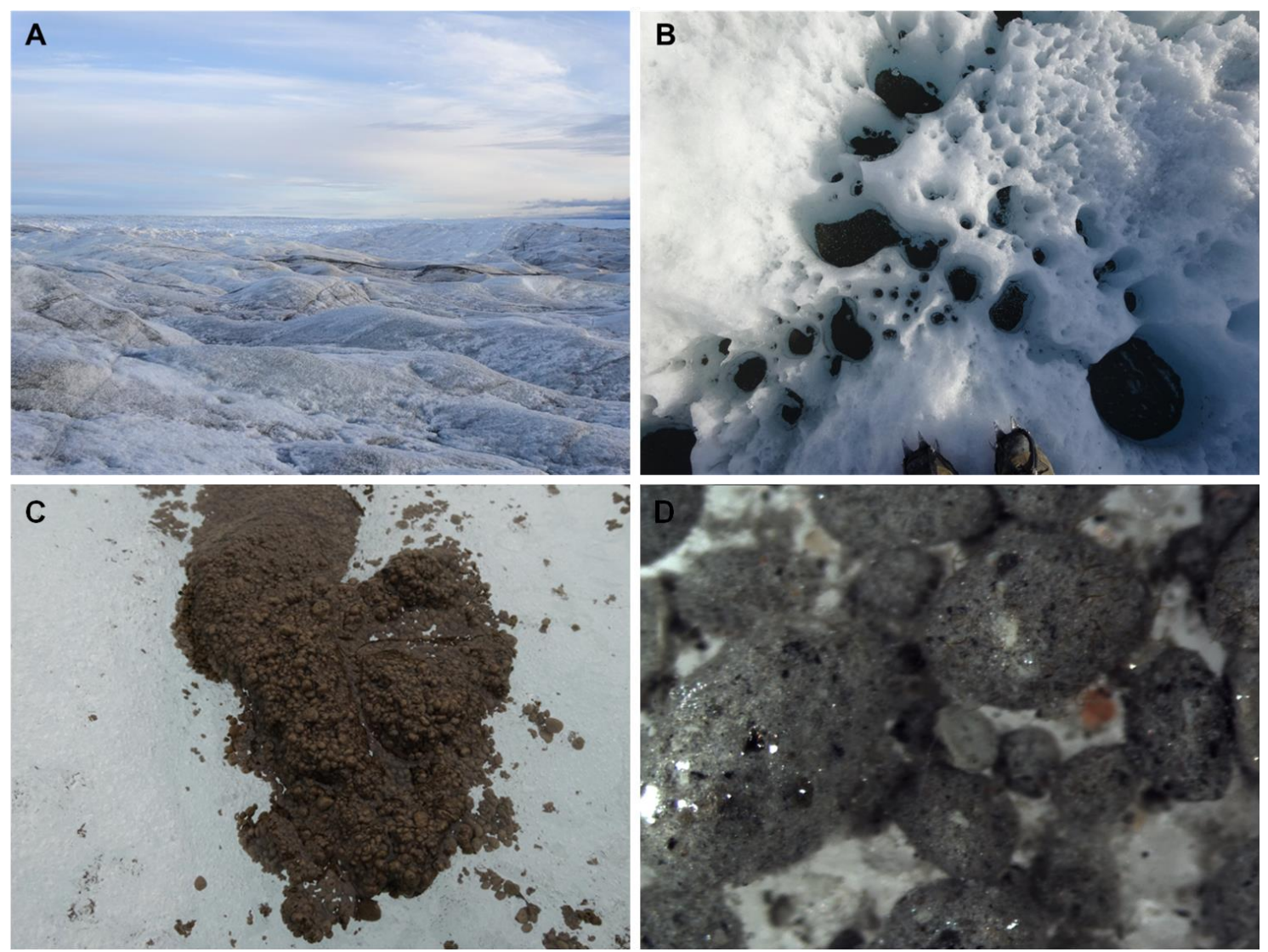

Fig.1. A - ice sheet (Greenland) - icy planet analogue, B - cryoconite holes on the ice sheet (Greenland), $\mathrm{C}$ - cryoconite granules - aggregations, D - cryoconite granules in high resolution with visible filaments of cyanobacteria - consortium of microorganisms.

active even under ice during polar night in the Antarctic (e.g. Tanabe et al. 2008; Bielewicz et al. 2011). In cryoconite granules the most abundant groups of organisms are archaea, cyanobacteria, heterotrophic bacteria, algae, fungi, and protists (Kaczmarek et al. 2015). Glacier extremophiles possess lipids and produce anti-freeze proteins and extracellular polymeric substances (EPS), which serve as cryo- and osmo-protectants (Feller and Gerday 2003; Boetius et al. 2015). Moreover, microorganisms in cryoconites cooperate, form different relations and control each other (e.g. Takeuchi et al. 2001; Vonnahme et al. 2015; Gokul et al. 2016). So far, astrobiological studies have been conducted on a single strains of prokaryotes or microinvertebrates (e.g., Johnson et al. 2011) but never on a consortium of microorganisms like cryoconite granules. Only ca. $1 \%$ of bacteria are culturable whereas the rest may be detected only in natural environment (Amann et al. 2001; Hugenholtz et al. 1998). Thus in previous experiments mainly culturable organisms were used. Therefore, previous astrobiological experiments on the single strains do not reflect true survival response of microorganisms to extreme environments. Only the holistic approach - using of whole consortium, can reflect the true functioning of its nature, and cryoconite biota is promising models for such experiments in astrobiology.

\section{Invertebrates}

Most of astrobiological research focuses mainly on prokaryotic organisms (e.g., Horneck 2000; Hoover and Gilichinsky 2001; Abbot et al. 2013; Baqué et al. 2013). However, some invertebrates like Tardigrada, 
Rotifera, Nematoda and Crustacea, were also proposed and used in astrobiological experiments (e.g., Gaubin et al. 1990; Jönsson et al. 2008; Fontaneto et al. 2012). Despite the facts that glaciers may constitute a climatic analogy to icy planets or moons, extremophiles, like micro animals inhabiting glaciers, are often neglected in literature and their potential use in astrobiology has been given no consideration so far. A groups of invertebrates, mainly Tardigrada and Rotifera, commonly inhabiting glaciers are known to survive exposition to extreme physical and chemical conditions (e.g., Jönsson et al. 2008; Rebecchi et al. 2009 a,b; Zawierucha et al. 2015). Both groups have the ability to enter cryptobiosis. This is a unique state of biological organization where the metabolic rate is reduced and the disaccharides trehalose and sucrose, stress-related gene families, along with heat shock proteins and dsup proteins are of great significance (e.g., Clegg 2001; Hashimoto et al. 2016).

\section{Tardigrada}

Tardigrades (usually less than $1 \mathrm{~mm}$ size) are the toughest animals in the world (Fig.2A). They are abundant group in cryoconite holes (Zawierucha et al. 2016b). They can survive multiple freezing, over drying, high and low temperatures as well as high doses of UV and ionizing radiation (e.g., Mihelčič 1963; Wright 2001; Guidetti et al. 2012). In the anhydrobiotic state they can survive in open-space and the exposure to the Martian conditions (e.g., Jönsson 2007; Jönsson et al. 2008; Persson et al. 2010; Horikawa 2012). Tardigrades used earlier in astrobiological research were solely limno-terrestrial (Jönsson et al. 2008; Rebecchi et al. 2009aand 2009b; Horikawa 2012; Erdmann and Kaczmarek 2016). Species inhabiting glaciers may be promising as a better adapted for possible survival on icy planets than taxa from soil or moss. Glacierdwelling black tardigrades (Fig.2A) in high mountains probably protect them-selves against high UV radiation with black pigmentation in cuticles (e.g., Greven et al. 2005; Zawierucha et al. 2015). Additionally, they permanently live in low glacial temperatures that oscillate around $0^{\circ} \mathrm{C}$. Thus, they may be a better astrobiological model than semi-terrestrial animals in terms of protection before UV radiation or freezing. Similar application was previously been considered in terms of limno-terrestrial tardigrades in the protection by unique proteins before irradiation of human cells (Hashimoto et al. 2016), or using trehalose in tissue engineering (e.g., Bradbury 2001).

\section{Rotifera}

Another common glacier dwelling group of animals that may serve as a good model in astrobiology research are Rotifera (Fig.2B), especially the class Bdelloidea (usually less than $1 \mathrm{~mm}$ size). These invertebrates inhabit all aquatic ecosystems including cryoconite holes (e.g., De Smet and Van Rompu 1994). Apart from their fast race of development and individual specimens ability to form a new stable population by parthenogenetic breeding, bdelloids are able to survive over drying each stage of their life cycle (e.g., Ricci 1998, 2001; Ricci and Caprioli 2005). What is also characteristic of Bdelloidea is their great resistance to ionizing radiation, which is due to their ability to fix DNA damage (Gladyshev and Meselson 2008; Krisko et al. 2011). All these features may indicate the usefulness of especially glacier Bdelloidea rotifers in astrobiological research as models exposed to freezing and the highest doses of irradiation.

\section{Summary}

Until now, glacier organisms have been widely studied in biological sciences (e.g., Sheridan et al. 2003; Anesio and Laybourn-Parry 2012; 

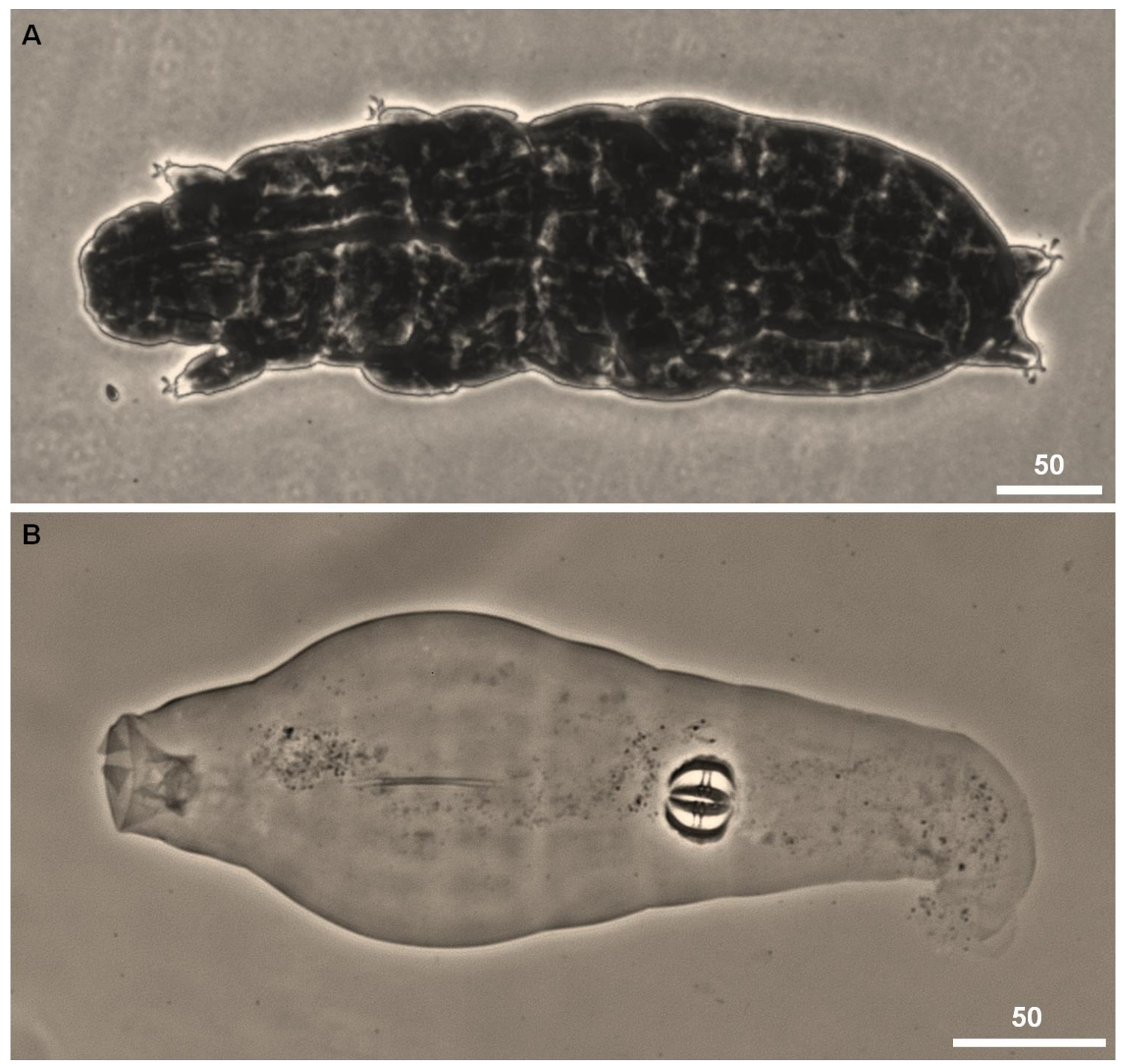

Fig.2. A - black pigmented water bear (Tardigrada) from high mountain glaciers, B - example of Rotifera from high mountain glaciers. Photos were taken under Phase Contrast Microscope (animals mounted on microscope slides in Hoyer's medium).

Yallop et al. 2012; Bellas et al. 2013; Edwards et al. 2013; Singh et al. 2014 a,b; Cook et al. 2015; Zawierucha et al. 2015). Thus, we can apply current knowledge on the glacier biota to find reliable and proper models in astrobiology for looking for analogies and survival strategies in terms of icy planets and moons.

The reasoning behind using cryoconite granules and glacier microinvertebrates as a specific models in astrobiology is as follows:

- Glacier organisms inhabit and reproduce in permanently cold habitats - high mountains and polar areas - one of the most extreme inland environments (e.g., Dastych et al. 2003; Boetius et al. 2015; Zawierucha et al. 2015).

- They possess lipids, proteins and extracellular polymeric substances which support cryo- and osmo- protection (e.g., Feller and Gerday 2003; Guidetti et al. 2012; Boetius et al. 2015).

- Those organisms (e.g., cyanobacteria, tardigrades, rotifers) have abilities to enter anabiosis and produce resting forms (e.g., Ricci 1998; Vincent 2007; Guidetti et al. 2012). 
- Some of organisms on Arctic and Alpine glaciers have dark pigment - the protection against UV radiation (e.g., Shain et al. 2000; Greven et al. 2005; Remias et al. 2005).

- Physical, chemical and biological conditions in ice-covered cryoconite holes form a unique combination among the surface waters on Earth and ice covered biotic and abiotic interactions may form astrobiological analogues (e.g., Vincent and Howard-Williams 2000; Tranter et al. 2004; Doran et al. 2010).

- Cooperating consortium of microorganisms like in cryoconite granules may reflect true survival response of organisms to extreme environments - organisms cooperate and compete with each other in cryoconites (e.g., Cook et al. 2016; Gokul et al. 2016; Lutz et al. 2016).

- They are exposed to dynamic changes e.g., freezing, the flushing of sediments, inter-hole water-sediment mixing as well as variation in pollution, radionuclides and heavy metals content (e.g., Mueller et al. 2001; Łokas et al. 2016; Zawierucha et al. 2016b).

- Cryoconite holes biota form clear truncated food web - easy understanding of ecological relations in icy areas (e.g., Hodson et al. 2008; Vonnahme et al. 2015; Zawierucha et al. 2016a).

- There is evidence that they can easily disperse from glacier to glacier (abilities to settle new areas) (e.g., Dabert et al. 2015; Gokul et al. 2016; Shain et al. 2016).

Further studies on glaciers biota could help to understand the mechanisms of how cryophilic organisms function. These could provide us with new valuable discoveries such as a new cryoprotectants, protection against UV radiation or the life histories of organisms in extreme habitats which can be beneficial to future astrobiological studies, in terms of multicellular organisms existing on icy planets.

\section{Acknowledgement}

Special thanks go to journal editor Tomasz Borszcz for tips and patience. Authors want to thank three anonymous reviewers and Daniel Stec (Jagiellonian University) for their comments and remarks on the manuscript. We are grateful to Marta Kołowrotkiewicz for proofreading of the text. Animals for pictures were kindly provided by Nozomu Takeuchi and Jun Uetake. Studies on the glacier dwelling invertebrates are supported by the National Science Centre grant no. NCN 2013/11/N/NZ8/00597 to K.Z.

\section{References}

Abbot D.S., Voigt A., Li D., et al. (2013) Robust elements of Snowball Earth atmospheric circulation and oases for life. Journal of Geophysical Research: Atmospheres 118: 6017-6027.

Amann R., Fuchs B.M., Behrens S. (2001) The identification of microorganisms by fluorescence in situ hybridisation. Current Opinion in Biotechnology 12: 231-236.

Anesio A.M., Laybourn-Parry J. (2012) Glaciers and ice sheets as a biome. Trends in Ecology \& Evolution 4: 219-225.

Baqué M., de Vera J.P., Rettberg P., et al. (2013) The BOSS and BIOMEX space experiments on the EXPOSE-R2 mission: Endurance of the desert cyanobacterium Chroococcidiopsis under simulated space vacuum, Martian atmosphere, UVC radiation and temperature extremes. Acta Astronomica 91: 180-186.

Bellas C.M., Anesio A.M., Telling J., et al. (2013) Viral impacts on bacterial communities in Arctic cryoconite. Environmental Research Letters 8045021 (9pp), doi:10.1088/1748-9326/8/4/045021 
Bielewicz S., Bell E., Kong W., et al. (2011) Protist diversity in a permanently icecovered Antarctic Lake during the polar night transition. The ISME Journal 5: 1559-1564.

Bradbury J. (2001) Of tardigrades, trehalose, and tissue engineering. The Lancet 358: 392.

Boetius A., Anesio A.M., Deming J.W., et al. (2015) Microbial ecology of the cryosphere: sea ice and glacial habitats. Nature Reviews Microbiology 13: 677-690

Christner B.C., Mosley-Thompson E., Thompson L.G., et al. (2001) Isolation of bacteria and 16S rDNAs from Lake Vostok accretion ice. Environmental Microbiology 3: 570-577.

Clegg J.S. (2001) Cryptobiosis - a peculiar state of biological organization. Comparative Biochemistry and Physiology Part B: Biochemistry and Molecular Biology 128: 613-624.

Chela-Flores J., Seckbach J. (2011) The Dry Valley Lakes, Antarctica: A key to evolutionary biomarkers on Europa and elsewhere. Instruments, Methods, and Missions for Astrobiology XIV. [In:] Proceedings of the SPIE (eds. R.B. Hoover, P.C. Davies, G.V. Levin, A.Y. Rozanov) vol. 8152, pp. 81520R-81520, R8. doi: $10.1117 / 12.898763$

Cook J., Edwards A., Bulling A., et al. (2016) Metabolome-mediated biocryomorphic evolution promotes carbon fixation in Greenlandic cryoconite holes. Environmental Microbiology 18: 4674-4686.

Cook J., Edwards A., Takeuchi N., Irvine-Fynn T. (2015). Cryoconite. The dark biological secret of the cryosphere. Progress in Physical Geography 40: 1-46.

Dabert M., Dastych H., Dabert J. (2015) Molecular data support the dispersal ability of the glacier tardigrade Hypsibius klebelsbergi Mihelčič, 1959 across the environmental barrier (Tardigrada). Ento- mologische Mitteilungen aus dem Zoologischen Museum Hamburg 17: 233-240.

Dastych H., Kraus H.J., Thaler K. (2003) Redescription and notes on the biology of the glacier tardigrade Hypsibius klebelsbergi Mihelcic, 1959 (Tardigrada), based on material from Ötztal Alps, Austria. Mitteilungen aus dem Zoologischen Museum Hamburg 100: 73-100.

De Smet W.H., Van Rompu E.A. (1994) Rotifera and Tardigrada from some cryoconite holes on a Spitsbergen (Svalbard) glacier. Belgian Journal of Zoology 124: 27-37.

Doran P.T., Lyons W.B., McKnight D.M. (2010) Life in Antarctic Deserts and other Cold Dry Environments.

Dudeja S., Bhattacherjee A.B., Chela-Flores J. (2012) Antarctica as model for the possible emergence of life on Europa. Life on Earth and Other Planetary Bodies. COLE Habitats and Astrobiology 24: 407-419.

Edwards A., Pachebat J.A., Swain M., et al. (2013) A metagenomic snapshot of taxonomic and functional diversity in an alpine glacier cryoconite ecosystem. Environmental Research Letters 8: 1-11.

Erdmann W., Kaczmarek Ł. (2016) Tardigrade in space researches- past and future. Origins of Life and Evolution of Biospheres. doi:10.1007/s11084-016-9522-1

Feller G., Gerday C. (2003) Psychrophilic enzymes: hot topics in cold adaptation. Nature Reviews Microbiology 1: 200-208.

Fishbaugh K. E., Head J. W. (2000) North polar region of Mars: Topography of circumpolar deposits from Mars Orbiter Laser Altimeter (MOLA) data and evidence for asymmetric retreat of the polar cap. Journal of Geophysical Research Atmospheres 105: 22455-22486.

Fontaneto D., Bunnefeld N., Westberg M. (2012) Long-Term Survival of Microscopic Animals Under Desiccation Is Not So Long. Astrobiology 12: 863-869. 
Gaubin Y., Delpoux M., Pianezzi B., et al. (1990) Investigations of the effect of cosmic rays on Artemia cysts and tobacco seeds; results of Exobloc II experiment, flown aboard Biocosmos 1887. International Journal of Radiation Applications and Instrumentation. Part D. Nuclear Tracks and Radiation Measurements 17: 133-143.

Gladyshev E., Meselson M. (2008) Extreme Resistance of Bdelloid Rotifers to Ionizing Radiation. Proceedings of the National Academy of Sciences 105: 5139-5144.

Greenberg R. (2005) Europa - The Ocean Moon. Praxis Publishing, UK, XV.

Greven H., Dastych H., Kraus H.J. (2005) Notes on the integument of the glacierdwelling tardigrade Hypsibius klebelsbergi Mihelčič, 1959 (Tardigrada). Entomologische Mitteilungen aus dem Zoologischen Museum Hamburg 102: 11-20.

Grzesiak J., Górniak D., Świątecki A., et al. (2015) Microbial community development on the surface of Hans and Werenskiold Glaciers (Svalbard, Arctic): a comparison. Extremophiles. 19(5): 885-97.

Gokul J.K., Hodson A.J., Saetnan E.R., et al. (2016) Taxon interactions control the distributions of cryoconite bacteria colonizing a High Arctic ice cap. Molecular Ecology 25, 3752-3767.

Guidetti R., Rizzo A.M., Altiero T., et al. (2012) What can we learn from the toughest animals of the Earth? Water bears (tardigrades) as multicellular model organisms in order to perform scientific preparations for lunar exploration. Planetary and Space Science 74: 97-102.

Hashimoto T., Horikawa D.D., Saito Y., et al. (2016) Extremotolerant tardigrade genome and improved radiotolerance of human cultured cells by tardigrade-unique protein. Nature Communications, 7: 12808.

Head J.W., Marchant D.R (2014) The climate history of early Mars: insights from the Antarctic McMurdo Dry Valleys hydro- logic system. Antarctic Science 26: 774800.

Hodson A., Anesio A.M., Tranter M., et al. (2008) Glacial ecosystems. Ecological Monographs 78: 41-67.

Hodson A., Cameron K., Bøggild C., et al. (2010). The structure, biological activity and biogeochemistry of cryoconite aggregates upon an Arctic valley glacier: Longyearbreen, Svalbard. Journal of Glaciology 56: 349-362.

Hodson A., Paterson H., Westwood K., Cameron K., Laybourn-Parry J. (2013). A blue-ice ecosystem on the margins of the East Antarctic ice sheet. Journal of Glaciology, 59: 255-268.

Horikawa D.D. (2012) Survival of tardigrades in extreme environments: A model animal for astrobiology. Anoxia. COLE Habitats and Astrobiology 21: 205-217. ISBN: 97894-007-1895-1

Horneck G. (2000) The microbial world and the case for Mars. Planetary and Space Science 48: 1053-1063.

Hoover R.B., Gilichinsky D. (2001) Significance to Astrobiology of MicroOrganisms in Permafrost and Ice. Permafrost Response on Economic Development, Environmental Security and Natural Resources NATO Science Series 76: 553-579.

Hugenholtz P., Goebel B.M., Pace N.R. (1998) Impact of culture independent studies on the emerging phylogenetic view of bacterial diversity. Journal of Bacteriology 180: 4765-4774.

Johnson A.P., Pratt L.M., Vishnivetskaya T., et al. (2011) Extended survival of several organisms and amino acids under simulated martian surface conditions. Icarus 211: 1162-1178.

Jönsson K.I. (2007) Tardigrades as a potential model organism in space research. Astrobiology 7: 757-766.

Jönsson K.I., Rabbow E., Schill R.O., et al. (2008) Tardigrades survive exposure to 
space in low Earth orbit. Current Biology 18: 729-731.

Kaczmarek Ł., Jakubowska N., CelewiczGołdyn S., et al. (2015) Cryoconite holes microorganisms (algae, Archaea, bacteria, cyanobacteria, fungi, and Protista)- a review. Polar Record 52: 176-203. doi:10.1017/S0032247415000637

Karl D.M., Bird D.F., Björkman K., et al. (1999) Microorganisms in the Accreted Ice of Lake Vostok, Antarctica. Science 286: 2144-2147.

Krisko A., Leroy M., Radman M., et al. (2011) Extreme anti-oxidant protection against ionizing radiation in bdelloid rotifers. Proceedings of the National Academy of Sciences 109: 2354-2357.

Langford H., Irvine-Fynn T., Edwards A., et al. (2014) A spatial investigation of the environmental controls over cryoconite aggregation on Longyearbreen glacier, Svalbard. Biogeosciences 11: 5365-5380.

Lutz S., Anesio A.M., Edwards A., Benning L.G. (2016) Linking microbial diversity and functionality of arctic glacial surface habitats. Environmental Microbiology, doi:10.1111/1462-2920.13494.

Łokas E., Zaborska A., Kolicka M., et al. (2016) Accumulation of atmospheric radionuclides and heavy metals in cryoconite holes on an Arctic glacier. Chemosphere 160: 162-172.

Marchant D.R., Head J.W (2014) Antarctic dry valleys: Microclimate zonation, variable geomorphic processes, and implications for assessing climate change on Mars. Icarus 192: 187-222.

Mueller D.R., Vincent W.F., Pollard W.H., et al. (2001) Glacial cryoconite ecosystems: a bipolar comparison of algal communities and habitats. Nova Hedwiga, Beiheft 123: 173-197.

Persson D., Halberg K.A., Jørgensen A., et al. (2010) Extreme stress tolerance in tardigrades: surviving space conditions in low earth orbit. Journal of Zoological
Systematics and Evolutionary Research 49: 90-97.

Porazińska D.L., Fountain A.G., Nylen T.H., et al. (2004) The biodiversity and biogeochemistry of cryoconite holes from McMurdo Dry Valley glaciers, Antarctica. Arctic, Antarctic, and Alpine Research 36: 84-91.

Priscu J.C., Adams E.E., Lyons W.B., et al. (1999). Geomicrobiology of subglacial ice above Lake Vostok, Antarctica. Science 286: 2141-2144.

Rebecchi L., Cesari M., Altiero T., et al. (2009a) Survival and DNA degradation in anhydrobiotic tardigrades. Journal of Experimental Biology 212: 4033-4039.

Rebecchi L., Altiero T., Guidetti R., et al. (2009b) Tardigrade resistance to space effects: first results of experiments on the LIFE-TARSE mission on FOTON-M3 (September 2007) Astrobiology 9: 581591.

Remias D., Lütz-Meindl U., Lütz C. (2005) Photosynthesis, pigments and ultrastructure of the alpine snow alga Chlamydomonas nivalis. European Journal of Phycology 40: 259-268.

Ricci C. (1998) Anhydrobiotic capabilities of bdelloid rotifers. Hydrobiology 387/388: 321-326.

Ricci C. (2001) Dormancy patterns in rotifers. Hydrobiology 446/447: 1-11.

Ricci C., Caprioli M. (2005) Anhydrobiosis in bdelloid species, populations and individuals. Integrative and Comparative Biology 45: 759-763.

Shain D.H., Halldórsdóttir K., Pálsson F., Aðalgeirsdóttir G., Gunnarsson A., Jónsson P., Lang S.A., Pálsson H. S., Steinpórssson S., Arnas E. (2016) Colonization of maritime glacier ice by bdelloid Rotifera. Molecular Phylogenetics and Evolution 98: 280-287.

Shain D.H., Carter M.R., Murray K.P., Maleski K.A., Smith N.R., McBride T.R., Michalewicz L.A., Saidel W.M. (2000) 
Morphologic characterization of the ice worm Mesenchytraeus solifugus. Journal of Morphology 246: 192-197.

Sheridan P.P., Miteva V.I., Brenchley J.E. (2003) Phylogenetic analysis of anaerobic psychrophilic enrichment cultures obtained from a Greenland glacier ice core. Applied and Environmental Microbiology 69: 2153-2160.

Singh P., Singh S.M., Dhakephalkar P. (2014a) Diversity, cold active enzymes and adaptation strategies of bacteria inhabiting glacier cryoconite holes of High Arctic. Extremophiles 18: 229-242.

Singh P., Hanada Y., Singh S.M., et al. (2014b) Antifreeze protein activity in Arctic cryoconite bacteria. FEMS Microbiology Letters 351: 14-22.

Sotin C., Tobie G. (2004) Internal structure and dynamics of the large icy satellites. Comptes Rendus Physique 5: 769-780.

Tanabe Y., Kudoh S., Imura S., Fukuchi M. (2008) Phytoplankton blooms under dim and cold conditions in freshwater lakes of East Antarctica. Polar Biology 31:199-208.

Takeuchi N., Kohshima S.S., Seko K. (2001) Structure, formation, and darkening process of albedo-reducing material (cryoconite) on a Himalayan glacier: a granular algal mat growing on the glacier. Arctic, Antarctic, and Alpine Research 33: 115-122.

Tranter M., Fountain A., Fritsen C., et al. (2004) Extreme hydrological conditions in natural microcosms entombed within Antarctic ice. Hydrological Processes 18: 379-387.

Uetake J., Tanaka S., Segawa T., et al. (2016) Microbial community variation in cryoconite granules on Qaanaaq Glacier, NW Greenland. FEMS Microbiology Ecology 92(9): 1-10.
Vincent W.F. (2007) Cold Tolerance in Cyanobacteria and Life in the Cryosphere. In J. Seckbach (ed.), Algae and Cyanobacteria in Extreme Environments 287-301. Springer.

Vincent W.F., Howard-Williams C. (2000) Life on snowball Earth. Science 287: 2421. Vonnahme T.R., Devetter M., Zárský J.D., et al. (2015) Controls on microalgal community structures in cryoconite holes upon high Arctic glaciers, Svalbard. Biogeosciences 13: 659-674.

Wharton R.A., McKay C.P., Simmons G.M., Parker B.C. (1985) Cryoconite holes on glaciers. Bioscience 35: 499-503.

Wilson L., Head J.W. (1981) Ascent and eruption of basaltic magma on the Earth and Moon. Journal of Geophysical Research: Solid Earth 86: 2971-3001. DOI: 10.1029/JB086iB04p02971

Wright J.C. (2001) Cryptobiosis 300 years on from van Leeuwenhoek: what have we learned about tardigrades? Zoologischer Anzeiger 240: 563-582.

Yallop M.L., Anesio A.M., Perkins R.G., et al. (2012) Photophysiology and albedochanging potential of the ice-algal community on the surface of the Greenland ice sheet. ISME Journal 6: 2302-2313.

Zawierucha K., Kolicka M., Takeuchi N., et al. (2015) What animals can live in cryoconite holes? A faunal review. Journal of Zoology 295: 159-169.

Zawierucha K., Ostrowska M., Vonnahme T.R., et al. (2016a) Diversity and distribution of Tardigrada in Arctic cryoconite holes. Journal of Limnology 75 : 545-559.

Zawierucha K., Vonnahme T.R., Devetter M., et al. (2016b) Area, depth and elevation of cryoconite holes in the Arctic do not influence Tardigrada densities. Polish Polar Research 37: 325-334. 